\title{
Acute Moderate Intensity Exercise Decreases Oxygen Saturation In Obese Women
}

\author{
Cornelius Coli ${ }^{1}$, Gadis Meinar Sari ${ }^{1,2}$, Purwo Sri Rejeki ${ }^{1,2 *}$ \\ ${ }^{1}$ Sport Health Science Study Program, Faculty of Medicine Universitas Airlangga \\ ${ }^{2}$ Department of Physiology Faculty of Medicine Universitas Airlangga \\ *purwo-s-r@ffk.unair.ac.id
}

\begin{abstract}
Obesity can lead to dysfunction of the pulmonary respiratory system by decreasing oxygen saturation. This is due to obese people experiencing impaired ventilation-perfusion mechanisms and disruption of gas exchange which results a decrease in oxygen saturation. This study aims to analyze acute moderate intensity exercise decreases oxygen saturation in obese women. This study is a true experiment with a randomized control group design posttest-only design using 14 obese women aged 19-24 years, body mass index (BMI) 27$33 \mathrm{~kg} / \mathrm{m} 2$, percentage body fat (PBF) above $30 \%$ and fasting blood glucose (FBG) below $100 \mathrm{mg} / \mathrm{dL}$, normal hemoglobin (Hb), normal systolic and diastolic blood pressure, normal resting heart rate and randomly divided into two groups, namely $\mathrm{CON}$ ( $\mathrm{n}=7$, control without intervention) and MIE ( $n=7$, moderate intensity exercise). Moderate intensity exercise intervention is carried out at 08.00-10.00 a.m. Moderate intensity exercise interventions carried out for 40 minutes using a treadmill. Blood sampling is done 10 minutes after the intervention. Measurement of oxygen saturation using a Pulse Oximeter. Data analysis techniques used the Independent-Samples T Test with the Statistical Package for Social Science (SPSS). The results obtained mean oxygen saturation at CON $(98.43 \pm 0.53) \%$ and MIE $(96.57 \pm 0.97) \%(p=0.001)$. Based on the results of the study concluded that moderate moderate intensity acute exercise reduces oxygen saturation in obese women. It is recommended to do further research by providing intensity exercise interventions that are carried out chronically (chronic exercise) in obese women.
\end{abstract}

Keywords: Cortisol Levels, Moderate Intensity Exercise, Obese Women, Oxygen Saturation, 


\section{STRADA Jurnal Ilmiah Kesehatan}

DOI: $10.30994 /$ sjik.v9i2.302

ISSN: 2252-3847 (print); 2614-350X (online)

Vol.9 No.2 November 2020 Page. $310-315$

\section{BACKGROUND}

Weight and height, are indicators of overweight and obesity, and are factors used to describe the health of a population. Over the past few decades, the prevalence of overweight and obesity has increased worldwide and has reached significant public health prelevance (Schienkiewitz, 2017). Obesity is an increasing global public health problem (Fruh et al., 2017) in developing countries including Indonesia (Harbuwono et al., 2018). This case, supported by the statement of the Consultant of World Health Organization (WHO) related to obesity has warned that an increase in the prevalence of obesity in developing countries (Prentice, 2006). In Indonesia, obesity has become a major health problem since the "double burden of disease" has affected Indonesia's population (Mihardja and Soetrisno, 2012). The prevalence of obesity needs to be done the right action in dealing with it.

The previous World Health Organization (WHO) report on diet, nutrition, and prevention of chronic diseases states that obesity is a major risk factor for all noncommunicable diseases (Prentice, 2006). This increase in morbidity and mortality associated with obesity is associated with obesity playing a role in a variety of chronic medical conditions, including cardiovascular and metabolic diseases, hyper-coagulable states, low back pain, osteoarthritis, and cancer. Obesity is also strongly associated with respiratory symptoms and diseases, including dyspnea activity, obstructive sleep apnea syndrome (OSAS), obese hypoventilation syndrome (OHS), chronic obstructive pulmonary disease (COPD), asthma, pulmonary embolism, and aspiration pneumonia. Besides the health risks associated with obesity can affect respiratory function (Mukhlis and Bakhtiar, 2015) can affect the decrease in oxygen saturation (SpO2) (Herdiyanti et al., 2018).

Health risks associated with obesity, including its effects on respiratory function. Respiratory muscle strength can experience weakness in obesity, where there is a decrease in maximal inspiratory pressure in obese subjects compared to control subjects for normal body weight. Respiratory muscle weakness in obesity has been linked to muscle weakness as a result of decreased compliance of the chest wall or reduced lung volume or can occur both (Mukhlis and Bakhtiar, 2015). This is because obesity has a disturbance in ventilation-perfusion mechanism and gas exchange disruption which results in a decrease in oxygen saturation (Herdiyanti et al., 2018). Oxygen saturation shows the adequacy of oxygenation or tissue perfusion, while decreasing oxygen saturation causes failure in oxygen transport (Andriyani and Hartono, 2013). Oxygen is substantially carried in blood bound to hemoglobin. A small portion in dissolved form. The amount of oxygen transported bound to hemoglobin is known as oxygen saturation $\left(\mathrm{SpO}_{2}\right)$ (Eroglu et al., 2018). Exercise will cause several changes in the body, one of which is the oxygen level in the blood. Under normal circumstances in the blood there is a reserve of oxygen. However, when doing exercise the body requires oxygen in large quantities to meet the need for energy. If the level of oxygen in the blood decreases beyond the normal limit will be very dangerous for the body (Simanjuntak et al., 2016). Research conducted by Eroglu et al. (2018) acute aerobic exercise reduces oxygen saturation. According to Simanjuntak et al. (2016) that acute physical exercise in basketball players has an increase in oxygen saturation. Besides Herdiyanti et al., (2018) explained that obesity has decreased oxygen saturation. Research conducted by Neto et al. (2014) concluded that acute exercise decreases oxygen saturation. Based on the above background, further research is needed regarding acute exercise of moderate intensity to changes in oxygen saturation in obesity. 


\section{STRADA Jurnal Ilmiah Kesehatan}

DOI: $10.30994 /$ sjik.v9i2.302

ISSN: 2252-3847 (print); 2614-350X (online)

Vol.9 No.2 November 2020 Page. $310-315$

\section{METHODS}

This study was a true experiment with a randomized control group posttest-only design study using 14 obese women aged 19-24 years, body mass index (BMI) $27-33 \mathrm{~kg} / \mathrm{m}^{2}$, percentage body fat (PBF) above 30\% and fasting blood glucose (FBG) $<100 \mathrm{mg} / \mathrm{dL}$, normal Hemoglobin $(\mathrm{Hb})$, blood pressure systole and diastole are normal, resting heart rate is normal and randomly divided into two groups, namely $\operatorname{CON}(n=7$, control without intervention) and MIE ( $\mathrm{n}=7$, moderate intensity exercise). All of these research procedures were approved by the Health Research Ethics Commission of the Faculty of Medicine, Airlangga University, Surabaya number 309/EC/KEPK/FKUA/2019.

MIE intervention is done by running on a treadmill with a moderate intensity of 6070\% $\mathrm{HR}_{\max }$ for 40 minutes (Dias et al., 2017; Wewege et al., 2017; Rahimi and Tayebi, 2013). The intervention was carried out at 08.00-10.00 a.m using a treadmill (Richter Treadmill Semi-Commercial Evolution (4.0 hp DC)). MIE intervention is done once (acute exercise).

Height measurements used a stadiometer (SECA, Chino, CA). Measurement of body weight, BMI and PBF, fat mass (FM), free fat mass (FFM) used TANITA (Body Composition Analyzer DC3607601 (2) -1604 FA, TANITA Corporation of America, Inc. USA). Measurement of blood pressure used a digital blood pressure meter (OMRON Model HEM-7130 L, Omron Co. JAPAN). Oxygen saturation $\left(\mathrm{SpO}_{2}\right)$ was measured using a Pulse Oximeter (PO 30 Pulse Oximeter, Beurer North America LP, 900 N Federal Highway, Suite 300, Hallandale Beach, FL 33009). FBG measurements using ACCUCHEK (ACCU-CHEK ${ }^{\circledR}$ Performa, Mannheim, Germany) with a unit of concentration of $\mathrm{mg} / \mathrm{dL}$. Hb measurement used Easy Touch (Easy Touch GCHb, Taiwan) with a unit of concentration $\mathrm{g} / \mathrm{dL}$.

Statistical analysis used statistical software packages for social science (SPSS). The normality test uses the Shapiro-Wilk test. Data that were normally distributed were tested using the Independent-Samples T Test with a significant level $(p<0.05)$. All data are displayed with mean \pm SD.

\section{RESULT}

The results of descriptive analysis of the research subjects' characteristics in each group can be seen in table 1 .

Table 1. Research subjects characteristics

\begin{tabular}{llccc}
\hline \multicolumn{1}{c}{ Variabel } & n & CON & MIE & \multirow{2}{*}{ p-value } \\
\cline { 3 - 4 } & & Mean \pm SD & Mean \pm SD & 0.573 \\
\hline Weight $(\mathrm{kg})$ & 7 & $75.21 \pm 6.15$ & $73.13 \pm 7.29$ & 0.793 \\
\hline Height $(\mathrm{m})$ & 7 & $1.58 \pm 0.04$ & $1.57 \pm 0.05$ & 0.372 \\
\hline Body Mass Index Tubuh $\left(\mathrm{kg} / \mathrm{m}^{2}\right)$ & 7 & $29.94 \pm 1.48$ & $29.28 \pm 1.15$ & 0.177 \\
\hline Fasting Blood Glucose $(\mathrm{mg} / \mathrm{dL})$ & 7 & $92.71 \pm 4.99$ & $88.14 \pm 6.79$ & 0.186 \\
\hline Hemoglobin $(\mathrm{g} / \mathrm{dL})$ & 7 & $15.60 \pm 1.97$ & $14.41 \pm 1.06$ & 0.271 \\
\hline Systolic Blood Pressure $(\mathrm{mmHg})$ & 7 & $114.28 \pm 5.34$ & $111.43 \pm 3.78$ & 0.611 \\
\hline Diastolic Blood Pressure $(\mathrm{mmHg})$ & 7 & $77.14 \pm 4.88$ & $75.71 \pm 5.34$ & 0.726 \\
\hline Resting Heartbeat $(\mathrm{bpm})$ & 7 & $78.14 \pm 11.35$ & $80.00 \pm 7.66$ & 0.306 \\
\hline Percentage Body Fat $(\%)$ & 7 & $46.34 \pm 3.70$ & $44.56 \pm 2.41$ & 0.280 \\
\hline Fat Mass $(\mathrm{kg})$ & 7 & $36.01 \pm 6.14$ & $32.73 \pm 4.63$ & 0.644 \\
\hline Free Fat Mass $(\mathrm{kg})$ & 7 & $41.37 \pm 4.06$ & $40.46 \pm 3.08$ & \\
\hline
\end{tabular}




\section{STRADA Jurnal Ilmiah Kesehatan}

DOI: $10.30994 /$ sjik.v9i2.302

ISSN: 2252-3847 (print); 2614-350X (online)

Vol.9 No.2 November 2020 Page.310-315

Based on Table 1, the Independent-Samples T Test shows that there are no significant differences in the mean data characteristics of research subjects in all groups. The result of oxygen saturation analysis of each group can be seen in table 2 .

Table 2. The Result of Statistic Analysis of Oxygen Saturation

\begin{tabular}{lccccc}
\hline Variable & Time & $\mathbf{n}$ & CON & MIE & \multirow{2}{*}{-value } \\
\cline { 3 - 5 } & & & Mean \pm SD & Mean \pm SD & \\
\hline Oxygen Saturation (\%) & Pre-exercise & 7 & $98.57 \pm 0.53$ & $98.14 \pm 0.89$ & 0.305 \\
\cline { 2 - 5 } & Post-exercise & 7 & $98.43 \pm 0.53$ & $96.57 \pm 0.97$ & $0.001^{*}$ \\
\hline
\end{tabular}

Based on Table 2, the Independent-Samples $\mathrm{T}$ Test shows that there is significant difference in the mean oxygen saturation $(p<0.05)$.

\section{DISCUSSION}

Based on the results of the study Table 2 shows that oxygen saturation in the MIE group was lower than the CON group. Based on the Independent-Samples T Test, it shows that there is a significant difference in the average oxygen saturation. These results are in line with the results of research conducted by Eroglu et al. (2018) concluded that aerobic exercise performed acutely can reduce oxygen saturation. Likewise the results of research conducted by Neto et al. (2014) concluded that acute exercise decreases oxygen saturation. The decrease in oxygen saturation in the MIE group is likely due to an intervention factor. This is due to when there is an increase in oxygen demand in the blood. Oxygen is substantially carried in blood bound to hemoglobin (Eroglu et al., 2018). Oxygen is bound to hemoglobin in red blood cells as it moves through the lungs, then it is distributed throughout the body through arteries. Hemoglobin that binds oxygen is called oxyhemoglobin $\left(\mathrm{HbO}_{2}\right)$, while hemoglobin that does not bind oxygen is called deoxihemoglobin $(\mathrm{Hb})$. Oxygen saturation level in arterial blood $\left(\mathrm{SaO}_{2}\right.$ oxygen saturation) shows the percentage of the amount of $\mathrm{HbO} 2$ to the amount of hemoglobin in the blood (Konica Minolta Sensing, Inc., 2006). Oxygen saturation is the ability of hemoglobin to bind oxygen. Intended as the degree of saturation or saturation $\left(\mathrm{SpO}_{2}\right)$ (Rupii, 2005). Decreased oxygen saturation in the MIE group due to muscle activity due to MIE can increase the temperature. Muscles that are working will release carbon dioxide, carbon dioxide acid released by the muscles that are working will increase the concentration of hydrogen ions (decreased $\mathrm{pH}$ ) in muscle capillaries. In addition, muscle temperature often rises from 2-30C which can increase $\mathrm{PO}_{2}$ to release $\mathrm{O}_{2}$ into the muscles, thereby decreasing the attractiveness of hemoglobin in oxygen thereby reducing oxygen saturation (Guyton and Hall, 2016). Any increase in body temperature can cause hemoglobin bonds and decreased oxygen levels. Body temperature is one of the factors that influence the speed of metabolism, because if body temperature rises there will be an acceleration of metabolic processes and metabolism will rise. The main factor of speed of metabolism is muscle activity (Ganong, 2009). According to Widiyanto and Yamim (2014) added that the factors that influence oxygen saturation include the amount of oxygen entering the lungs (ventilation), the speed of diffusion, and the capacity of hemoglobin to carry oxygen.

Decreased-oxygen saturation in the MIE group was also caused by obesity. Obesity occurs excessive accumulation of adipose tissue around the chest wall and abdomen. This 


\section{STRADA Jurnal Ilmiah Kesehatan}

DOI: $10.30994 /$ sjik.v9i2.302

will cause changes in respiratory mechanics that can cause interference with the ventilation-perfusion mechanism and interference with $\mathrm{O}_{2}$ and $\mathrm{CO}_{2}$ exchange which results in a decrease in $\mathrm{PO}_{2}$. A decrease in $\mathrm{PO}_{2}$ will cause a decrease in the amount of oxygen that is bound to each heme group on the hemoglobin molecule (\% saturation) (Rabec et al., 2011; Littleton, 2011). Changes to oxygen saturation stimulate peripheral chemoreceptors. Peripheral chemoreceptors will forward impulses to the respiratory control center to increase or decrease the frequency of breathing in response to changes in oxygen saturation (Coztanzo, 2014).

Respiratory muscle weakness in obesity has been linked to muscle weakness as a result of decreased compliance of the chest wall or reduced lung volume or can occur both (Mukhlis and Bakhtiar, 2015). This is because obesity has a disturbance in ventilationperfusion mechanism and gas exchange disruption which results in a decrease in oxygen saturation (Herdiyanti et al., 2018). Oxygen saturation shows the adequacy of oxygenation or tissue perfusion, while decreasing oxygen saturation causes failure in oxygen transport (Andriyani and Hartono, 2013). Oxygen is substantially carried in blood bound to hemoglobin. A small portion in dissolved form. The amount of oxygen transported bound to hemoglobin is known as oxygen saturation (SpO2) (Eroglu et al., 2018). Exercise will cause several changes in the body, one of which is the decreased oxygen level in the blood (Niko et al., 2018). Under normal circumstances there is a reserve of oxygen in the blood. However, when doing exercise the body requires large amounts of oxygen to meet the energy needs for muscle contraction, thus causing oxygen stores in the body. The decrease in oxygen storage causes a decrease in oxygen saturation, so that in the exercise group moderate intensity tends to have lower oxygen saturation compared to the control group.

\section{CONCLUSION}

Acute moderate intensity exercise performed for 40 minutes causes a decrease in oxygen saturation in obese women. Based on the results of the study it is recommended to do further research by comparing several training methods such as ergocycle training, resistance training to decrease oxygen saturation in obese women. Further research is carried out by comparing treadmill exercises conducted chronically with several kinds of exercise intensity, such as low intensity, moderate intensity and high intensity to changes in oxygen saturation.

\section{REFERENCES}

Andriani, A. and Hartono, R. 2013. Saturasi Oksigen dengN Pulse Oxumetry dalam 24 Jam Pada Pasien Dewasa Terpasang Ventilator di Ruang ICU Rumah Sakit Panti Wilasa Citarum Semarang. Jendela Nursing Journal, 2(1): 1-7.

Dias, K.A., Ingul, C.B., Tjonna, A.E., Keating, S.E., Gomersall, S.R., Follestad, T., Hosseini, M.S., Hollekim-Strand, S.M., Ro, T.B., Haram, M., Huuse, E.M., Davies, P.S.W., Cain, P.A., Leong, G.M. and Coombes, J.S. 2017. Effect of High-Intensity Interval Training on Fitness, Fat Mass and Cardiometabolic Biomarkers in Children with Obesity: A Randomised Controlled Trial. Sports Medicine, 48(3):733-746. https://doi.org/10.1007/s40279-017-0777-0.

Eroglu, H., Okyaz, B., Turkcapar, U. 2018. The Effect of Acute Aerobical Exercise on Arterial Blood Oxygen Saturation of Athletes. Journal of Education and Training Studies, 6(9): 74-79. https://doi.org/10.11114/jets.v6i9a.3562. 


\section{STRADA Jurnal Ilmiah Kesehatan}

DOI: $10.30994 /$ sjik.v9i2.302

ISSN: 2252-3847 (print); 2614-350X (online)

Vol.9 No.2 November 2020 Page.310-315

Fruh, S.M. 2017. Obesity, Risk factors, complications, and strategies for Sistanable Longterm Weight Management. American Association of Nurse Practitioners, 29(2017): S3-S14. http://doi.org/10.1002/2327-6924.12510.

Harbuwono, D.S., Pramono, L.A., Yunir, E., Subekti, I. 2018. Obesity and Central Obesity in Indonesia: Evidence from a National Health Survey. Medical Journal of Indonesia, 27(2): 114-120. https://doi.org/10.13181/mji.v27i2.1512.

Herdiyanti, S.N., Koesoema, T.J., Ningrum, F.H. 2018. Pengaruh Deep Breathing Akut Terhadap Saturasi Oksigen Dan Frekuensi Pernapasan Anak Obesitas Usia 7-12 Tahun. Jurnal Kedokteran Diponegoro, 7(2): 1211-1221. http://ejournal3.undip.ac.id/index.php/medico.

Ganong, WF. 2009. Buku Ajar Fisiologi Kedokteran Ganong. Edisi 22, Jakarta: EGC.

Guyton, Ermita I. Ibrahim Ilyas editorial. 2016. Guyton dan Hall : Buku Ajar Fisiologi Kedokteran Edisi Revisi Berwarna Ke-12. Singapura : Elsevier Singapore.

Mihardja, L. and Soetrisno U. 2012. Prevalence and determinant factors for overweight and obesity and degenerative diseases among young adults in Indonesia. JAFES, 27(1):77- 81 .

Mukhlis, M. and Bakhtiar, A. 2015. Obstructive Sleep Apneu (OSA), Obesitas Hypoventilation Syndrome (OHS) dan Gagal Napas. Jurnal Respiasi, 1(3): 94-102.

Neto, G.R., Sousa, M.S.C. Silva1, G.V.C. Gil1, A.L.S., Salles, B.F. and Novaes, J.S. 2014. Acute resistance exercise with blood flow restriction effects on heart rate, double product, oxygen saturation and perceived exertion. Clinical Physiology and Functional Imaging. https://doi.org/10.1111/cpf.12193.

Prentice, A.M. 2006. The emerging epidemic of obesity in developing countries. Int $J$ Epidemiol, 35(1):93-9.

Rahimi, A. and Tayebi, S.M. 2013. The Effect of a Single Session of Moderate and Heavy Intensity Weight-lifting Exercise on Plasma Testosterone and Cortisol in Elite Male Weight-lifters. Annals of Applied Sport Science, 1(1):1-5.

Schienkiewitz, A., Gert, B.M., Kuhnert, M.R., Lange, C. 2017. Overweight and obesity among adults in Germany. Journal of Health Monitoring, 2(2): 20-27. http://doi.org/10.17886/RKI-GBE-2017-038.

Simanjuntak, R.H., Engka, J.N.A., Marunduh, S.R. 2016. Pengaruh Latihan Fisik Akut Terhadap Saturasi Oksigen Pada Pemain Basket Mahasiswa Fakultas Kedokteran Unsrat. Jurnal e-Biomedik (eBm), 4(1): 20-24.

Wewege, M., van den Berg, R., Ward, R.E. and Keech, A. 2017. The effects of highintensity interval training vs. moderate-intensity continuous training on body composition in overweight and obese adults: a systematic review and metaanalysis. Obesity Reviews, 18(6):635-646. https://doi.org/10.1111/obr.12532 